\title{
Pengaruh Edukasi Pola Makan dan Senam terhadap Kadar Gula Darah Pada Penderita DM Tipe 2
}

\author{
Bela Febriana Selfi ${ }^{1}$, Demsa Simbolon ${ }^{2}$, Kusdalinah $^{3}$ \\ ${ }^{1,2,3}$ Jurusan Gizi, Politeknik Kesehatan Kementrian Kesehatan Bengkulu, Indonesia \\ Email: belafeberianaselfi02@gmail.com
}

\begin{abstract}
The Influence of Eating and Gymnastic Education on Blood Sugar Levels in Type 2 DM Patients. The high prevalence of diabetes mellitus (DM) type 2 one risk factor is an unhealthy lifestyle, especially an unhealthy diet and lack of physical activity. Education followed by physical activity required to provide benefits to the body as a way of exercise can lower blood sugar. The recommended physical activity such as gymnastics, Gymnastics is aerobic physical exercise with a series of movements in a way to follow the rhythm of the music. The study aims to determine the effect of diet and exercise education on blood sugar levels in people with type 2 $\mathrm{dm}$ in Bengkulu City Puskesmas Lingkar Timur years 2018. This quasi-experimental research design.consists of 30 intervention and 30 control group. Gymnastics held 3 times a week for 1 week and education 1 time for 1 week, with an examination of the blood sugar levels of pretest and posttest. Data collection equipment consists of glucometers and bathroom scales and microtoice. The used statistical test Chi-Square test, t-dependent, and t-independent. The results of the study the characteristics of most women, age range 40-70 years intervention group and a control group 32-79 years, the average BMI in the intervention group is $24.21 \mathrm{~m} 2$ and $24.33 \mathrm{~m} 2$ in the control group, the intervention group showed that the levels of blood sugar before an average of $271.90 \mathrm{mg} / \mathrm{dl}$, while the results of the blood sugar level after an average of 225.93 $\mathrm{mg} / \mathrm{dl}$. in the control group blood sugar levels before an average of $278.27 \mathrm{mg} / \mathrm{dl}$ whereas the blood sugar level results after an average of $285.67 \mathrm{mg} / \mathrm{dl}$. Based on the statistical test that no educational influence diet and exercise on blood sugar levels in patients with type $2 \mathrm{dm}$ p-value of 0.002. Expected to Type 2 diabetic patient's diet, increasing exercise and increased activity at home.
\end{abstract}

Keywords: Blood sugar levels, Education diet, Exercise

\begin{abstract}
Abstrak: Pengaruh Edukasi Pola Makan dan Senam Terhadap Kadar Gula Darah pada Penderita DM Tipe 2. Tingginya prevalensi Diabetes mellitus (DM) tipe 2 salah satu faktor resiko adalah gaya hidup yang kurang sehat, terutama pola makan tidak sehat dan aktifitas fisik yang kurang. Edukasi diikuti dengan aktivitas fisik diperlukan untuk memberikan manfaat bagi tubuh karena dengan cara berolahraga dapat menurunkan gula darah. Aktivitas fisik yang dianjurkan berupa senam, Senam adalah latihan fisik aerobik dengan serangkaian gerakan dengan cara mengikuti irama musik. Penelitian bertujuan mengetahui pengaruh edukasi pola makan dan senam terhadap kadar gula darah pada penderita dm tipe 2 di Puskesmas Lingkar Timur Kota Bengkulu tahun 2018. Desain penelitian ini quasi eksperimen terdiri dari 30 kelompok intervensi dan 30 kelompok kontrol. Senam dilaksanakan 3 kali seminggu selama 1 minggu dan edukasi 1 kali selama 1 minggu, dengan pemeriksaan kadar gula darah pre-test dan post-test. Alat pengumpulan data terdiri dari: gluco meter serta timbangan injak dan microtoice. Uji statistik yang digunakan uji Chi-Square, $t$ dependen dan $t$ independen. Hasil penelitian menjelaskan bahwa karakteristik sebagian besar perempuan, rentang umur kelompok intervensi 40-70 tahun dan kelompok kontrol 32-79 tahun, rata-rata IMT pada kelompok intervensi yaitu 24,21 $\mathrm{m}^{2}$ dan kelompok kontrol yaitu $24,33 \mathrm{~m}^{2}$, pada kelompok intervensi menunjukan bahwa kadar gula darah sebelum rata-rata $271,90 \mathrm{mg} / \mathrm{dl}$, sedangkan pada hasil kadar gula darah sesudah rata-rata 225,93 $\mathrm{mg} / \mathrm{dl}$ pada kelompok kontrol kadar gula darah sebelum rata-rata $278,27 \mathrm{mg} / \mathrm{dl}$ sedangkan pada hasil kadar gula darah sesudah rata-rata $285,67 \mathrm{mg} / \mathrm{dl}$. Hasil analisis lanjutan menunjukan ada pengaruh edukasi pola makan dan senam terhadap kadar gula darah pada penderita DM tipe 2 dengan nilai $p$-value 0.002 . Berdasarkan hasil tersebut disarankan agar penderita dm tipe 2 untuk mengatur pola makan, meningkatkan olahraga dan memperbanyak aktivitas dirumah.
\end{abstract}

Kata kunci: Kadar gula darah, Edukasi pola makan, Senam 
World Health Organization (WHO) melaporkan bahwa DM semakin berkembang dan sekarang menjadi ancaman masyarakat dunia (WHO, 2011). Sebesar 90\% penderita DM di dunia masuk kedalam klasifikasi DM tipe 2. Prevalensi penderita DM tipe 2 di seluruh dunia sebesar 285 juta (6.4\%) pada tahun 2010 dan akan meningkat menjadi 439 juta $(7.7 \%)$ pada tahun 2030. WHO memastikan bahwa peningkat pada penderita DM tipe 2 paling banyak terjadi di Negara berkembang salah satunya adalah Indonesia. Indonesia menempati urutan ke-4 yang tinggi terutama penderita DM tipe 2 dengan prevalensi 9.1 juta, setelah India, Cina dan Amerika Serikat (Listiana, dkk 2015).

Prevalensi DM untuk Provinsi Bengkulu tahun 2007 berdasarkan diagnosa tenaga kesehatan dan gejala adalah sebesar $1,1 \%$ dan prevalensi pada tahun 2013 berdasarkan diagnosa tenaga kesehatan dan gejala terjadi peningkatan adalah sebesar 2,1\% (Riskesdas, 2013). Edukasi diikuti dengan aktivitas fisik diperlukan untuk memberikan manfaat bagi tubuh karena dengan cara berolahraga dapat menurunkan tekanan darah, menjaga berat badan, meningkatkan kekuatan tubuh dan meningkatkan kontrol gula darah (Listiana, dkk 2015 dan Sumangkut, dkk 2013). Aktivitas fisik yang dianjurkan berupa senam diabetes, Senam adalah latihan fisik aerobik bagi penderita diabetes dengan serangkaian gerakan yang dipilih secara segaja dengan cara mengikuti irama musik (Nugraha, dkk 2016).

Pada setiap tahunya terjadi peningkatan penderita DM Tipe 2 dari tahun ketahun, kurangnya pengetahuan tentang pola makan dan senam diduga salah satu yang menyebabkan kadar gula darah penderita DM Tipe 2 meningkat dan penderita DM Tipe 2 meningkat pada setiap tahunnya. Maka perlu memberikan informasi kepada penderita DM dengan cara memberikan edukasi tentang pola makan dan senam diabetes, maka penulis tertarik untuk melakukan penelitian tentang "Pengaruh Edukasi Pola Makan dan Senam Diabetes terhadap Kadar Gula Darah Sewaktu pada Penderita DM Tipe-2".

\section{METODE}

Penelitian ini merupakan penelitian eksperimen dengan rancangan quasi eksperiment yang dilakukan pada bulan April-Mei di Puskesmas Lingkar Timur Kota Bengkulu. Teknik pengambilan sampel purposive sampling, terdiri dari 30 kelompok intervensi dan 30 kelompok kontrol. Senam dilaksanakan selama
60 menit 3 kali seminggu selama 1 minggu dan edukasi 1 kali selama 1 minggu, dengan pemeriksaan kadar gula darah pre-test dan posttest. Alat pengumpulan data meliputi terdiri dari: Easy touch, timbangan injak dan microtoice. Uji statistik yang digunakan yaitu uji Chi-Square, $t$ test dependen dan $t$-test independen.

\section{HASIL}

Tabel 1. Distribusi Frekuensi berdasarkan Karakteristik Umur, Berat Badan Tinggi Badan dan IMT

\begin{tabular}{|c|c|c|c|c|c|}
\hline \multirow[t]{2}{*}{ Karakteristik } & \multicolumn{2}{|c|}{ Intervensi } & \multicolumn{2}{|c|}{ Kontrol } & \multirow{2}{*}{$\underset{\text { value }}{p}$} \\
\hline & $\begin{array}{l}\text { Min- } \\
\text { Max }\end{array}$ & $\begin{array}{c}\text { Mean } \pm \\
\text { SD }\end{array}$ & $\begin{array}{l}\text { Min- } \\
\text { Max }\end{array}$ & $\begin{array}{c}\text { Mean } \pm \\
\text { SD }\end{array}$ & \\
\hline Umur & $\begin{array}{r}40- \\
70\end{array}$ & $\begin{array}{r}58,00 \pm \\
9,055\end{array}$ & $32-79$ & $\begin{array}{l}59,07 \pm \\
10,255\end{array}$ & 0,671 \\
\hline Berat Badan & $\begin{array}{r}42- \\
75\end{array}$ & $\begin{array}{r}57,63 \pm \\
8,257\end{array}$ & $41-85$ & $\begin{array}{r}61,17 \pm \\
1,972\end{array}$ & 0,160 \\
\hline Tinggi Badan & $\begin{array}{r}145- \\
167\end{array}$ & $\begin{array}{r}154,10 \\
\pm 5,006\end{array}$ & $\begin{array}{r}145- \\
169\end{array}$ & $\begin{array}{l}158,47 \\
\pm 6,202\end{array}$ & 0,004 \\
\hline IMT & $\begin{array}{r}17,94- \\
30,4 \\
\end{array}$ & $\begin{array}{r}24,21- \\
2,879\end{array}$ & $\begin{array}{r}18,00- \\
36,79\end{array}$ & $\begin{array}{r}24,33 \pm \\
4,025\end{array}$ & 0,000 \\
\hline
\end{tabular}

Tabel 1 di atas menunjukan rata-rata umur kelompok kontrol yaitu 59,07 tahun dan pada kelompok intervensi yaitu 58,00 tahun, rata-rata berat badan kelompok kontrol yaitu $61,17 \mathrm{~kg}$ dan pada kelompok intevensi yaitu $57,63 \mathrm{~kg}$, sedangkan rata-rata tinggi badan kelompok kontrol yaitu 158,47 cm dan pada kelompok intervensi yaitu 145,10 , dan rata-rata IMT pada kelompok kontrol yaitu $24,33 \mathrm{~m}^{2}$ sedangkan pada kelompok intervensi yaitu $24,21 \mathrm{~m}^{2}$.

Tabel 2. Distribusi Frekuensi berdasarkan Karakteristik Jenis Kelamin dan IMT

\begin{tabular}{lrrrrr}
\hline \multirow{2}{*}{ Variabel } & \multicolumn{2}{c}{ Intervensi } & \multicolumn{2}{c}{ Kontrol } & \multirow{2}{*}{-value } \\
\cline { 2 - 5 } & $\mathbf{n}$ & $\boldsymbol{\%}$ & $\mathbf{n}$ & $\boldsymbol{\%}$ & \\
\hline Jenis Kelamin & & & & & \\
$\quad$ Laki-laki & 1 & 3,3 & 15 & 50 & 0,000 \\
$\quad$ Perempuan & 29 & 96,7 & 15 & 50 & \\
IMT & & & & & \\
$\quad$ Normal & 12 & 20 & 11 & 18,3 & \\
$\quad$ Tidak & 18 & 30 & 19 & 31,7 & 1.000 \\
$\quad$ Normal & & & & & \\
\hline
\end{tabular}

Tabel di atas menunjukan bahwa sebagian besar responden baik kelompok intervensi dan kelompok kontrol berjenis kelamin perempuan, Sedangkan pada IMT pada kelompok intervensi dengan presentase kategori normal 20\% dan tidak normal $30 \%$. Kelompok kontrol persentase IMT dengan kategori normal 18,3\% dan tidak normal $31,7 \%$. 
Tabel 3. Pengaruh Kadar Gula Darah Sebelum dan Sesudah Kelompok Kontrol dan Kelompok Intervensi pada Penderita Diabetes mellitus Tipe 2

\begin{tabular}{|c|c|c|c|c|c|c|}
\hline \multirow{2}{*}{$\begin{array}{c}\text { Kadar Gula } \\
\text { Darah }\end{array}$} & Mix-Max & Mean \pm SD & Mix-Max & Mean \pm SD & \multirow{2}{*}{$\begin{array}{c}\text { Selisih } \\
\text { Mean }\end{array}$} & \multirow{2}{*}{$\begin{array}{l}* p \\
\text { value }\end{array}$} \\
\hline & \multicolumn{2}{|c|}{ Sebelum Intervensi } & \multicolumn{2}{|c|}{ Sesudah Intervensi } & & \\
\hline Intervensi & $191-539$ & $271,90 \pm 77,190$ & $142-360$ & $225,93 \pm 53,631$ & $-45,97$ & 0,000 \\
\hline Kontrol & $179-505$ & $278,27 \pm 84,272$ & $199-493$ & $285,67 \pm 82,244$ & 7,4 & 0,102 \\
\hline
\end{tabular}

Hasil penelitian pada kelompok intervensi menunjukan bahwa rata-rata kadar gula darah sebelum 271,90 mg/dl dan sesudah 225,93 mg/dl. Sedangkan pada kelompok kontrol sebelum $278,27 \mathrm{mg} / \mathrm{dl}$ dan sesudah $285,67 \mathrm{mg} / \mathrm{dl}$. Selisih mean menunjukan kelompok intervensi kebih besar daripada kelompok kontrol.

Tabel 4. Perbedaan Kadar Gula Darah antara Kelompok Kontrol dan Intervensi

\begin{tabular}{lccc}
\hline $\begin{array}{c}\text { Kadar Gula } \\
\text { Darah }\end{array}$ & Min-Mix & Mean \pm SD & p-value \\
\hline Kontrol & $199-493$ & $285,67 \pm$ & \\
& & 82,224 & 0,002 \\
Intervensi & $142-360$ & $225,93 \pm$ & \\
& & 53,631 & \\
\hline
\end{tabular}

Berdasarkan Tabel 4 telah diuji statistik dengan uji t-test independent diatas menunjukan hasil uji statistik nilai rata-rata kadar gula darah pada kelompok intervensi $225,93 \mathrm{mg} / \mathrm{dl}$ dan kelompok kontrol 285,67 mg/dl Sehingga didapatkan $p$-value yaitu $(\leq 0,05)$.

\section{PEMBAHASAN}

\section{Karakteristik Responden}

Berdasarkan hasil penelitian, diketahui bahwa jenis kelamin pada penelitian ini tidak homogen karena sebagian besar responden pada kelompok intervensi perempuan, sebanyak 29 orang $(96,7 \%)$ sedangkan laki-laki hanya 1 orang $(3,3 \%)$. Pada kelompok kontrol perempuan sebanyak 15 orang $(50 \%)$ sedangkan pada lakilaki 15 orang (50\%). Hasil penelitian menunjukan bahwa responden perempuan lebih banyak dari pada laki-laki. Berdasarkan kelompok umur, responden yang paling muda adalah 32 tahun dan yang paling tua 79 tahun. Pada hasil dapat diketahui bahwa pada kelompok intervensi rata-rata responden berusia 40-70 tahun sedangkan pada kelompok kontrol rata-rata umur 32-79 tahun.

Berdasarkan penelitian ini data IMT tidak homoge karena kategori IMT pada kelompok intervensi dengan persentase kategori normal $20 \%$ dan tidak normal 30\%, sedangkan pada kelompok kontrol presentase IMT dengan kategori normal 18,3\% dan tidak normal 31,7\%. Pada hasil dapat diketahui bahwa kategori IMT normal 24 orang dengan persentase $40 \%$ dan tidak normal 36 orang dengan persentase $60 \%$.

\section{Pengaruh Edukasi Pola Makan terhadap Kadar Gula Darah}

Hasil uji statistik $t$-test dependen yang dilakukan didapatkan p-value 0,102 yaitu menunjukan bahwa tidak ada pengaruh edukasi pola makan dengan kadar gula darah. Berdasarkan hasil pengukuran kadar gula darah responden yang sudah mendapatkan edukasi pola makan selama 1 kali dalam 1 minggu, sebagian besar masih memiliki kadar gula darah tidak terkontrol. Hal ini bisa terjadi karena beberapa sebab; kemungkinan besar sebagian responden masih tidak patuh pada prinsip diet yang diberikan melalui edukasi, atau pengetahuan tentang prinsip diet masih sangat rendah sehingga jumlah makanan yang dikonsumsi tidak sesuai dengan status gizi responden, bisa kelebihan atau kekurangan, jadwal makan yang dapat berpengaruh pada kadar gula darah, dan masih banyak mengkonsumsi jenis makanan pantangan, terutama makanan yang tinggi karbohidrat.

Hasil wawancara menunjukan bahwa pasien dengan gula darah yang tidak terkontrol hampir semuanya belum pernah mengikuti edukasi pola makan dan tidak menerapkan pola makan $3 \mathrm{~J}$ (Jenis, Jumlah dan jadwal) ataupun tidak sesuai dengan diet diabetes mellitus. Selain itu, juga tampak bahwa rata-rata responden tidak mengetahui tentang jenis bahan makanan yang mengandung karbohidrat kompleks dan sederhana sehingga kadar gula darah akan meningkat karena makanan yang dikonsumsi bisa lebih banyak mengadung karbohidrat sederhana yang sebenarnya tidak boleh dikonsumsi bagi penderita diabetes.

Penelitian Gondosari (2009) menjelaskan bahwa mengkonsumsi terlalu banyak karbohidrat sederhana dapat menyebabkan gula darah meningkat tajam, yang akan menyebabkan tubuh memproduksi hormon insulin. Fungsi utama insulin adalah menurunkan gula darah, dan membawah lemak ke seluruh tubuh. Hal lain yang berpengaruh yaitu prinsip diet " $3 \mathrm{~J}$ " yaitu 
tepat jadwal, jumlah dan jenis. Semakin bertambah usia seseorang maka akan terjadi penurunan fungsi organ tubuh yaitu otak yang berhubungan dengan daya ingat. Dengan bertambahnya umur penderita diabetes mellitus maka kemampuan untuk melakukan perencanaan makan sehari-hari juga akan semakin menurun. Makanan akan menaikan gula darah, satu sampai dua jam setelah makan, gula darah mencapai paling tinggi. Dengan mengatur perencanaan makan yang meliputi jumlah, jenis dan jadwal diharapkan dapat mempertahankan atau menurunkan kadar gula darah. Sehingga diperlukan pemberian edukasi pola makan dengan lebih memperhatikan aspek-aspek penting seperti berapa kali memberikan edukasi pola makan sehingga apa yang diinformasikan dapat diterima dengan baik.

Penelitian ini sejalan dengan penelitian yang dilakukan oleh Jasmani, dkk (2016) bahwa ada hubungan anatara pelaksanaan edukasi oleh perawat dengan kadar gula darah pada pasien DM diwilayah Puskesmas Jati Datar Kabupaten Lampung Tengah dengan $p$ value: 0,044. Penelitian ini juga sejalan dengan penelitian yang dilakukan Wandasari (2013) terhadap 60 sampel, dimana hasil penelitian ini menunjukan tidak ada hubungan anatara pola makan dengan kejadian diabetes mellitus tipe 2 tetapi menjadi resiko faktor diabetes mellitus. Sebagian besar responden tidak pernah mengatur pola makan dibandingkan yang sering mengatur pola makan. Perubahan pola hidup dan pola makan yang berlebihan menyebabkan gangguan metabolisme zat-zat makanan baik berupa karbohidrat, protein dan lemak yang menyebabkan penyakit diabetes mellitus.

Berdasarkan hasil tersebut maka hasil penelitian ini menujukan bahwa sebagaian besar responden menganggap bahwa edukasi pola makan yang diberikan kurang dapat mereka pahami dan pada penelitian ini edukasi diberikan hanya 1 kali sehingga informasi yang diberikan tidak dapat mereka terima dengan baik sehingga tidak memberikan dampak terhadap penurunan ataupun perbedaan sebelum dan sesudah diberikannya edukasi pola makan terhadap kadar gula darah pada pasien diabetes mellitus tipe 2 di Puskesmas Lingkar Timur Kota Bengkulu Tahun 2018.

\section{Pengaruh Edukasi Pola Makan dan Senam terhadap Kadar Gula Darah}

Hasil penelitian menunjukan bahwa nilai $p$-value 0,000 yaitu menujukan bahw terdapat perbedaan edukasi pola makan dan senam terhadap kadar gula darah. Sebab edukasi pola makan yang baik dan diikuti dengan aktivitas fisik (senam) dapat membantu penyerapan mengenai DM yang diperoleh dari penyuluhan atau edukasi pola makan dan aktivitas fisik.

Hal ini sesuai dengan pendapat Soegondo (2009) menunjukan bahwa faktor lingkungan yang menyebabkan terjadinya Diabetes mellitus Tipe 2 adalah aktivitas fisik yang kurang, nutrisi yang berlebihan dan obesitas, diabetes mellitus tipe 2 juga meningkat disebabkan hal, misalnya berkurangnya kematian akibat infeksi dan meningkatnya faktor resiko yang disebabkan oleh gaya hidup yang kurang baik, seperti kegemukan, aktivitas fisik dan pola makan yang tidak sehat. Olahraga terus menerus, kadar lemak dalam darah akan berkurang.

Hasil penelitian sejalan dengan hasil penelitia oleh Sutiawati, dkk (2013) dengan hasil bahwa terdapat pengaruh edukasi gizi terhadap pengetahuan, pola makan dan kadar gula darah pada pasien DM Tipe 2 di RSUD Lanto Pasewang. Demikian juga oleh penelitian Sharifirad, dkk (2009) yang menyatakan bahwa edukasi gizi dapat meningkatkan pengetahuan pasien dan mengurangi glukosa darah puasa pasien. Kadar glukosa darah puasa yang diberikan edukasi gizi dan tidak, memiliki perbedaan signifikan dalam glukosa darah dari dua kelompok dan dikurangi secara signifikan pada kelompok kasus dibandingkan dengan kelompok kontrol $(p<0,001)$.

Hasil ini juga menunjukan kesesuaian dengan teori yang menyatakan bahwa pemberian edukasi pada pasien DM dapat memberikan pengaruh terhadap kadar glukosa darah. Tujuan edukasi pada dasarnya untuk mengubah pemahaman individu kelompok, dan masyarakat di bidang kesehatan sebagai sesuatu yang bernilai, mandiri, dalam mencapai tujuan hidup sehat, serta dapat menggunakan fasilitas pelayanaan kesehatan yang ada dengan tepat dan sesuai atau secara umum untuk mengubah perilaku kesehatan masyarakat (Jasmani, dkk 2016).

Pemberian edukasi dapat meningkatkan pengetahuan pasien tentang gaya hidup sehat dan upaya mengontrol kadar glukosa darahnya, sedangkan pengetahuan adalah faktor predisposisi terjadinya perilaku, seperti pengetahuan seseorang atau masyarakat tersebut terhadap apa yang akan dilakukan, keyakinan, kepercayaan, nilai-nilai, dan sebagainya (Jasmani, dkk 2016). Menurut Notoadmodjo (2007) pengetahuan adalah hasil dari tahu, dan terjadi setelah orang melakukan pengindraan terhadap suatu objek tertentu. Penginderaan itu terjadi melalui panca indera 
manusia yakni indera penglihatan, pendengaran, penciuman, rasa dan raba. Sebagian besar penginderaan manusia diperoleh melalui mata dan telinga.

Perilaku kesehatan pada dasarnya adalah semua aktivitas atau kegiatan seseorang baik yang dapat diamati (observabel) maupun yang tidak dapat diamati (unobservable) yang berkaitan dengan pemeliharaan dan peningkatan kesehatan. Pemeliharaan kesehatan mencakup mencegah dan melindungi diri dari penyakit dan masalah kesehatan lain, meningkatkan kesehatan dan mencari penyembuhan apabila sakit atau terkena masalah kesehatan (Notoatmodjo, 2012).

Melakukan olahraga yang baik dan teratur membuat peningkatan aliran ke otot dengan cara pembukaan kapiler (pembukaan darah kecil ke otot), dan hal ini akan menurunkan tekanan darah pada otot yang pada gilirannya akan meningkatkan penyediaan dalam jaringan otot itu sendiri. Dengan demikian akan mengurangi gangguan metabolisme karbohidrat pada penderita diabetes mellitus, sehingga menurunkan kadar glukosa darah (Utomo, dkk 2016).

Menurut Soegondo (2009) secara akut pengaruh olah raga adalah menurunkan kadar glukosa plasma dan menurunkan penyimpanaan energi jaringan, selain itu juga dapat mengembangkan sensivitas insulin dan kontrol glikemik, dengan tanpa menurunkan berat badan dan dengan olah raga juga diharapkan dapat menurunkan berat badan penderit DM tipe 2 . Olahraga atau latihan fisik diperkirakan dapat mengakibatkan konsumsi oksigen dan energi meningkat sekitar 20 kali lipat, sehingga penggunaan glukosa juga dapat digunakan dalam jumlah besar dengan tidak membutuhkan sejumlah insulin. Hal ini diperkirakan karena serat otot menjadi lebih permeabel terhadap glukosa akibat kontraksi dari otot itu sendiri. Pada pasien Diabetes mellitus latihan fisik merupakan program yang sangat penting dalam mencegah terjadinya komplikasi diabetik, karena dengan berolah raga maka glukosa banyak digunakan oleh otot untuk bergerak secara aktif, dan Glikogen di hati digunakan untuk memenuhi glukosa dalam tubuh, sehingga kadar glukosa darah tetap stabil atau menurun (Nugraha, dkk 2016).

Hal ini sejalan dengan penelitian yang dilakukan oleh Nugraha, dkk (2016) yaitu hasil penelitian dengan menggnakan uji t-test dependent didapatkan nilai $p$-value $=0,000$ maka kriteria pengujian adalah $p$-value $(<0,005)$ maka disimpulkan bahwa terdapat perbedaan kadar gula darah pasien DM Tipe 2 sebelum dan sesudah senam diabetes, dengana danya penurunan kadar gula darah sesudah senam yang mengikuti senam di Poliklinik penyakit dalam RSUD dr.Slamet Garut Tahun 2016.

Hasil ini memiliki kesamaan dengan penelitian yang dilakukan oleh Salindeho, dkk (2016) dengan judul "Pengaruh senam diabetes mellitus terhadap kadar gula darah pada penderita diabetes mellitus tipe 2 di sanggar senam persadia Kabupaten Gorontalo" dengan hasil bahwa pada pasien yang mengikuti senam ada perbedaan kadar gula darah pasien DM Tipe 2 sebelum dan sesudah senam.

Penelitian ini juga memiliki kesamaan dengan penelitian yang dilakukan oleh Utomo, dkk (2012) hasil penelitian menunjukan terdapat perbedaan kadar gula darah sewaktu sebelum dan sesudah intervensi pada kelompok terpapar (nilai $p=0,0001$ ), pada kelompok tidak terpapar (nilai $p=0,0001$ ) dengan penurunan rata-rata gula darah pada kelompok terpapar 2,3 kali lebih besar dari pada kelompok tidak terpapar yang artinya bahwa senam efektif menurunkan kadar gula darah.

Pada saat latihan jasmani otot-otot tubuh, sistem jantung dan sirkulasi darah serta pernafasan diaktifkan. Oleh sebab itu metabolisme tubuh, keseimbangan cairan dan elektrolit serta asam basa harus menyesuaikan diri. Otot-otot akan menggunakan asam lemak bebas dan glukosa sebagai tenaga atau energi. Apabila latihan jasmani dimulai glukosa yang berasal yang berasal dari glikogen di otot-otot pada saat latihan jasmani mulai dipakai sebagai sumber tenaga. Apabila latihan jasmani terus ditingkatkan maka sumber tenaga dan glikogen otot berkurang, selanjutnya akan terjadi pemakaian glukosa darah dan asam lemak bebas. Makin ditingkatkan porsi olahraga makin meningkat pula pemakaian glukosa yang berasal dari cadangan glikogen hepar. Apabila latihan ditingkatkan lagi, maka sumber tenaga terutama yang berasal dari asam lemak dan lipopisis jaringan lemak (Persadia, 2000).

Berdasarkan hasil uji statistik dengan uji $t$ test independent didapatkan hasil bahwa pengaruh edukasi pola makan dan senam Diabetes mellitus terhadap perubahan kadar gula darah pre-test dan post-test pada kelompok intervensi dan kelompok kontrol, mean pre-test $271,9 \mathrm{mg} / \mathrm{dl}$ dan posttest $225,93 \mathrm{mg} / \mathrm{dl}$ dimana terjadi penurunan nilai rata-rata kadar gula darah setelah intervensi edukasi pola makan dan senam. Nilai signifikan yang diperoleh dengan uji t-test independent pada perbandingan kelompok kontrol dan kelompok intervensi adalah p-value $0,0002(p<0,05)$. Interpretasi hasil yang diperoleh 
adalah terdapat perbedaan penurunan kadar gula darah sewaktu secara signifikan pada kelompok kontrol dan kelompok intervensi.

\section{SIMPULAN}

Hasil penelitian ini menunjukan bahwa ada pengaruh edukasi pola makan dan senam terhadap kadar gula darah pada penderita DM Tipe 2 di Puskesmas Lingkar Timur Kota Bengkulu dengan ditunjukkan nilai $p$-value $(\leq 0,05)$, serta tidak ada pengaruh edukasi pola makan terhadap kadar gula darah pada penderita DM Tipe 2 di Puskesmas Lingkar Timur Kota Bengkulu dengan nilai $p$-value $(\geq 0,05)$, dan

\section{DAFTAR PUSTAKA}

Badan Penelitian dan Pengembangan Kesehatan Kementerian RI. 2013. Riset Kesehatan Dasar (Riskesdas) Tahun 2013. www.depkes.go.id/resources/download/ge neral/Hasil\%20Riskesdas\%202013.pdf. (Diakses pada 1 Oktober 2018)

Gondosari, Aleysius H. 2009. Karbohidrat Sederhana. http://5Elemen.com. (Diakses 26 April 2018).

Jasmani, J., dan Tori Rihiantoro. 2016. Edukasi dan Kadar Glukosa Darah pada Pasien Diabetes. Jurnal Keperawatan. Vol.12, No.1:140-149

Listiana, N., Mulyasari, I., \& Paundrianagari, M. D. 2015. Hubungan asupan karbohidrat sederhana dan aktivitas fisik dengan kadar glukosa darah pada penderita diabetes mellitus tipe 2 wanita usia 45-55 tahun di kelurahan Gedawang kecamatan Banyumanik kota Semarang. Jurnal Gizi dan Kesehatan, 7(13).

Nugraha, A., Kusnadi, E., \& Subagja, S. 2016. Kadar Gula Darah Sebelum dan Sesudah Melaksanakan Senam Diabetes pada Pasien Diabetes Melitus Tipe II. Jurnal Ilmiah Kesehatan, 9(2).

Notoatmodjo, Soekidjo. 2012. Metodelogi Penelitian Kesehatan. Jakarta: Rineka Cipta.

Persadia. 2000. Senam Diabetes Seri 1. Jakarta: Yayasan Diabetes Indonesia.

Sumangkut, S., Supit, W., \& Onibala, F. 2013. Hubungan Pola Makan Dengan Kejadian Penyakit Diabetes Melitus Tipe-2 Di Poli Interna Blu. rsup. Prof. Dr. RD Kandou Manado. Jurnal Keperawatan, 1(1).

Sharifirad, G., Entezari, M. H., Kamran, A., \& Azadbakht, L. 2009. The effectiveness of terdapat perbedaan edukasi pola makan dan senam terhadap kadar gula darah pada penderita DM Tipe 2 di Puskesmas Lingkar Timur Kota Bengkulu dengan hasil nilai $p$-value $(\leq 0,05)$.

\section{SARAN}

Penderita diabetes mellitus perlu untuk meningkatkan mengatur pola makan 3J (Jenis, Jumlah, dan Jadwal). Serta perlunya meningkatkan olahraga secara rutin 3 kali seminggu dan memperbanyak aktivitas dirumah, serta menggali pengetahuan tentang penyakit diabetes mellitus untuk mengendalikan kadar gula darah.

nutritional education on the knowledge of diabetic patients using the health belief model. Journal of research in medical sciences: the official journal of Isfahan University of Medical Sciences, 14(1), 1.

Salindeho, A., Mulyadi, N., \& Rottie, J. 2016. Pengaruh Senam Diabetes Melitus Terhadap Kadar Gula Darah Penderita Diabetes Melitus Tipe 2 Di Sanggar Senam Persadia Kabupaten Gorontalo. JURNAL KEPERAWATAN, 4(1).

Soegondo. 2009. Diabetes the silent killer. http://www.medicastore.com/diabetes/ (Diakses pada 12 Oktober 2017).

Soegondo, Sidartawan dkk. 2009. Penyebab Penyakit Diabetes Melitus. In: Utama H. Penatalaksanaan diabetes mellitus terpadu. Jakarta: Fakultas Kedokteran UI

Sutiawati, M., Jafar, N., Yustini. 2013. Pengaruh Edukasi Gizi Terhadap Pengetahuan, Pola Makan dan Kadar Glukosa Darah Paien Diabetes Melitus Tipe 2 RSUD Lanto'DG Pasewang Jeneponto. Jurnal: Media Gizi Masyarakat Indonesia. Vol.2, No. 2:78-84.

Utomo, O. M., Azam, M., \& Ningrum, D. N. A. 2012. Pengaruh senam terhadap kadar gula darah penderita diabetes. Unnes Journal of Public Health, 1(1).

Wandansari, K. 2013. Hubungan Pola Makan Dan Aktivitas Fisik Dengan Kejadian Diabetes Mellitus Tipe 2 di RSUD Dr. Moewardi Surakarta. [Skripsi]. Universitas Muhammadiyah Surakarta.

World Health Organization. 2011. Penanganan Diabetes Mellitus di Rumah Sakit Kecil dan Berkembang. Jakarta: EGC. 